\title{
Human Resource Development Management (Study at Adonara Timur Senior High School, Distict of Flores Timur, Nusa Tenggara Timur - Indonesia)
}

\author{
Rafael S.B Bin Ola ${ }^{1}$, Jeffri.S.J.Lengkong ${ }^{2}$, Joseph Ph. Kambey ${ }^{3}$ \\ Magister Education Management Postgraduate Program \\ Manado State University, Indonesia
}

\begin{abstract}
The purpose of this study is to find out how the planning, implementation and results of the implementationof human resource development management in senior high school (SMA Negeri I) Adonara Timur, districof Flores Timur. This study used qualitative research methods. The collection technique is done byobservation or observation, interview, and documentation study. The process of data analysis is carried outbefore data is obtained and during data collection is done (data reduction). The inherent oddities are re-verified in the presentation of the data and then the final conclusion is found to be fundamental. Theconclusion of the research is the implementation of human resource development management in SMANegeri I Adonara Timur implemented by passing the stages in management, namely: planning, organizing,implementation, and supervision. Planning is implemented by the school leadership by making regularobservations to all of his subordinates. Thus, from these observations the leadership can determine whatneeds are needed and what development programs are needed in an effort to improve the quality ofeducation in SMA Negeri I Adonara Timur. Implementation of human resource development program inSMA Negeri I Adonara Timur has been going on and on continuously. Implementation of human resourcedevelopment in SMA Negeri I Adonara Timur is through training and education, concretely implemented inthe form of activities such as curriculum socialization, upgrading, workshops, training, panel discussions,scientific discussions, and the existence of the plan of study program continued for certain teachers.Implementation of these programs on a regular basis and is mandatory and received direct supervision fromthe leadership. 3) Implementation of human resource development in SMA Negeri I Adoara Timur produceresults in accordance with the targeted. The results are measured by the high percentage of graduation aswell as the high percentage in the selection of admissions at state universities at provincial and nationallevels.
\end{abstract}

\section{Key words: Managemen, Human Resources Development}

\section{Introduction}

Human resources within an organization, including educational organizations require good development in an effort to improve their performance in order to contribute to the achievement of goals. Increased performance of human resources will impact on the better performance of the organization in carrying out its role. Human resource management is a factor that will determine on the performance of the organization. The accuracy of utilizing and developing human resources as well as integrating in a unity of movement and direction of the organization will be important for the improvement of organizational capability in achieving its objectives. In the world of education, especially in schools, the role of teachers or teachers is very important. Teachers are actors who can not be excluded from an educational unit or school. Because of that important role, it should be the teachers or teachers equipped with competent skills and knowledge.

Development of human resources in the field of education is something that can not be negotiable. This is in accordance with the needs in the field that require education pengelolah in order to make the planning, organizing, implementing, and evaluation of education independently. The world of education also demands management in various pathways and levels of education and the quality of educators in accordance with the standards of educators and educational personnel, so that community goals immediately materialized. 
Speaking of an educational institution or a school, it can not be separated from the role of a leader or manager (principal) of the school. According to Mantja (2007: 138), in the schooling schooling system in Indonesia, the principal becomes the highest official of a school. Along with his position, the principal becomes the person most responsible for things that happen in school. Included in it is the development of teachers' human resources.

The principal in leading the school institution is the one who determines the center point and the rhythm of a school. Principals as top leaders have the authority and power and effective leadership strategies to organize and develop their subordinates professionally. Furthermore, it can be said that the success of the school is the success of the principal. In this case the principal is one component of education that plays the most in improving the quality (quality) of education, one of which is degan way to develop the human resources of his subordinates in a professional manner. But in different places, according to Mantja (2007: 138) a true teacher must have a high sense of responsibility for the task that he embani. In other words it can be said that the responsibility for developing the ability to teach (competence) must arise also from within the teacher itself. Because a teacher is naturally committed to developing and of course has the ability to think so as to be able to innovate in developing ability and knowledge. The development of human resources is characterized by the actions of teachers who are able to encourage themselves to increase their capacity. From the brief description that has been described, it can be said that the development of human resources of teachers in an educational institution is very important to do. Because by developing the ability of teachers by itself the quality of education produced will also be better.

The problems of human resource development in schools especially regarding the development of teaching staff resources and administration should be an important agenda in every educational unit. No exception in SMA Negeri I Adonara Timur. With geographical location far enough from the provincial capital, of course SMA Negeri I Adonara Timur often have difficulty in efforts to improve the quality of education. Distribution of infrastructure and facilities is often hampered, thus often disrupting the smoothness of teaching and learning activities. Obviously, these obstacles are a big challenge for the leadership of SMA Negeri I Adonara Timur in maintaining and even improving the quality of education. Here the professionalism and competence of teachers and administration is necessary. so that despite the limited facilities, but able to maximize the existing. Therefore, management of human resource development in a school is very important then, the researcher is interested to do research related to it. Moreover, the absence of researchers in detail see what kind of portrait of managerial human resource development at schools in the Adonara area, which is still a newly developed area. Therefore, researchers interested in conducting research with the title: Management Development study at SMA Negeri I Adonara Timur, East Flores District, East Nusa Tenggara Republic of Indonesia

\section{Literature Review}

Theoretical Steps in the Implementation of Human Resources Management in School.

Etymologically, Management's word comes from the Latin word Manus and Agere combined into Managere meaning deal (Kambey, 2012: 1) While lexically, management says it means the process of using resources effectively to achieve goals (Big Indonesian Dictionary , 2011).

Furthermore, the term management is defined in several definitions in accordance with the point of view used. According to Harold and Hein Weirich in Kambey (2012), management is defined as the process of designing and maintaining an environment in which people work together in groups to achieve certain goals efficiently. While G. R Terry in Kambey (2012: 2), defines management as the achievement of a predetermined objective through the efforts of others. There is also an understanding of management by Siagian in Kambey (2012: 2), defines management as a process to get things done through others. From the various notions described, it can be said that no definition of the word management is adapted to the reference point of each expert. So none can be considered the most correct and valid.

Management as a science has branches of science that are born from the basic science of management itself. One of them is education management. Management education is a branch of management science that is relatively young age. The old term of management education is administration. Management education has several goals, one of which is to provide educational staff with theories about the process of management and administration of education. From there came the steps to develop the faculty's abilities. It requires a management system to develop human resources (especially teachers) in schools (Mustari, 2014: $1-3)$. 
From some sense of management by experts who have been mentioned before, it can be concluded that management is a discipline that is basically used as a way or path to achieve a planned goal by utilizing existing human resources. Management is also an art in utilizing existing human resources by regulating, directing, and placing people in positions in accordance with their expertise in order to achieve the goals that have been planned.

\section{Theoretical Steps in the Implementation of Human Resources Management in School}

In theory, there are many steps or ways used in the framework of human resource development of educators in schools. According to Mustari (2014: 222) and Mantja (2007: 61-62), there are several steps that are most commonly used include: (1) Guidance in the form of instructions given to faculty or employees at the time carry out the task. (2) Through exercises both internally and externally. (3) Promotion for appointment. (4) Workshop or workshop, (5) courses. (6) Formal education or further study. (7) Job training and rotation. (8) Upgrading. (9) Seminar.

From the steps put forward by the experts above, it certainly can not be applied to all educational platforms. Because not all schools have the same facilities and costs. Therefore the role and policy of the principal is necessary in determining the steps or methods used in developing the resources of the teachers and staff.

\section{Supporting Factors}

Many things play a role as supporting factors to achieve the development of human resources in a school. In this section, there will be two factors that are considered the most important role in the development of human resources in schools, namely: the role of the principal and the awareness of the teacher to grow.

One of the tasks a principal has to do in human resource management at school is to assess teachers and school keepers as their subordinates. Assessment of the implementation of this work is important because it will lead to career development and improvement. Which is one of the applications of human resource development management in schools. According to Mantja (2007: 60-61), a principal must know clearly the abilities, advantages, or even shortcomings of his subordinates based on the observations of their work. In practice, a principal must have a list of job execution assessments. With these assessments, it will also provide a capital grip for staff in knowing their strengths and weaknesses. The task of the principal as a manager is to carry out management functions in the form of planning, organizing, implementing and evaluating teacher performance.

To develop a teacher performance plan, the principal involves all elements of school personnel. With the implementation of human resource development management by the school principal, the development of teachers' resources will run smoothly and smoothly. Teja argues that the desire to continue to grow and develop should be the need of a professional teacher (Mantja, 2007: 60-62) . Correspondingly, Glickman in Mantja (2007: 61), argues that responsibility for the development of competence must arise also from within teachers.

Therefore, in developing the competence of teaching staff in schools, the role of the teachers themselves is very decisive or give a big impact. The development of teacher competence not only includes knowledge and understanding, but also expected is the willingness of the teachers themselves to continuously improve their competency eligibility.

\section{Inhibiting Factors}

According to Hasibuan (2002: 95-96), theoretically there are several factors that often become obstacles in the development of human resources, among others are: (1) Difficult to get a trainer or instructor who is expert in transferring knowledge consequently, the target is not achieved. (2) Inadequate development facilities are also inhibiting factors and tend to complicate the smooth development. (3) limited development funds so that education and training are done very simply and do not meet training standards. (4) Different awareness and background of the participants makes development inhibited. (5) The less harmonious and distorted and unsystematic curriculum makes achievement of the target inhibited or even unattainable.

The inhibiting factors are often experienced by most of the many schools. Moreover, schools are in developing areas. Lack of funds, facilities, and skilled workers in providing additional training and education makes the process of developing teachers' resources very stunted and even unattended 


\section{Research Method}

This study used qualitative research methods. The meaning of qualitative research is describing a particular situation obtained through observation, interviews, and documentation studies. Bogdan and Taylor in Moleong, (2007: 4) define a qualitative methodology as a research procedure that produces descriptive data in the form of written or oral words of people and observed behavior. Qualitative research techniques are considered in accordance with research on human resources development management implementation in SMA Negeri I Adonara Timur, East Flores District, NTT. Because in the research, researchers try to understand about a working system in human resource development management. The location of the research is in SMA Negeri I Adonara Timur, East Flores Regency, Nusa Tenggar Timur, Republic of Indonesia.

This study was conducted for three months, starting from January 2017 until March 2017. Using primary data and secondary data. Primary data were obtained from interviews both oral and written to the head of the school, vice principal, and teacher teachers. Data analysis used by researcher to make data easier to understand is by using interactive model from Miles and Huberman in Sugiyono (2011: 246) consisting of raw data collection, data display, data reduction, and verification or conclusion.

\section{Results and discussion}

Result

1. Planning of Human Resource Development Management at SMAN I Adonara Timur, East Flores District, NTT. Planning in the implementation of human resource development program (teacher and administration) at SMAN I Adonara Timur implemented by road, principals make observations on the performance of the teachers and administration. Then proceed with a joint evaluation. The goal is to analyze the necessary needs and actions to be taken in developing teacher competence.

2. Implementation of Human Resource Development at SMAN I Adonara Timur, East Flores District, NTT. Implementation of human resource development in SMAN I Adonara Timur has been there and has long existed. In its implementation, the development of human resources in SMA Negeri I Adonara Timur is implemented through several program activities that are carried out, among others: deliberation of subject teachers (MGMP) at school, sub-district, district and provincial levels, curriculum socialization, upgrading, internships, scientific seminars, panel discussions, meetings and meetings, workshops, and planning for further studies for some teachers.

3.Results Achieved from Human Resource Development at SMAN I Adonara Timur, Kabupaten Flores Timur, NTT. The results achieved from the implementation of human resource development in SMA Negeri I Adonara Timur are classified into two types of results, namely: the results in particular and the results in general. The results are specifically the results obtained directly by subjects who follow human resource development program in SMA Negeri I Adonara Timur. The intended subjects are teachers and administration. While the general result is the result of the increase of teacher resources in SMA Negeri I Adonara Timur to graduates from SMA Negeri I Adonara Timur itself. The general result is seen in the increasing percentage of graduation from students in SMA Negeri I Adonara Timur which reached up to $100 \%$ in three consecutive years.

\section{Discussion}

Departing from the research findings previously described, then on this subject will be described and will be discussed about the findings of scientific research. This discussion intends as a relevant and coherent theoretical justification between research results and theories in human resource development management. In accordance with the research focus, this discussion is also described systematically and sequentially as follows:

1. Planning of human resources development management in SMA Negeri I Adonara Timur. The planning of human resource development (teacher and administration) at SMAN I Adonara Timur is done by road, principal as the highest leader in school to observe the performance of teachers and administration. Then from the observation is followed by evaluation with the vice principals. The objective is to analyze the necessary needs and actions to be taken in developing teacher competence and as much as possible predict what needs are needed in order to improve the quality of education in SMA Negeri I Adonara Timur. In line with that, Handoko (2001: 52) argues that planning is the core of management because planning helps to reduce uncertainty in the future. So that the decision makers (principals) menggunanakan limited resources 
in an efficient and effective. In addition to Handoko's opinion on human resource development planning, Siagian (1998: 44) also argues that planning is absolutely necessary in an organization including educational organizations to deal with future uncertainty situations. With good planning it will ensure the implementation of educational resource development in SMA Negeri I Adonara Timur is good so it will produce results (quality of education) as expected.

2. Implementation of Human Resource Development in SMA Negeri I Adonara Timur, East Flores District. In the implementation of human resource development in SMA Negeri I Adonara Timur, the emphasis is on training and knowledge development by MGMP, scientific seminars, internships, socialization, upgrading, and educational planning or further study. This is in line with the thought of Notoadmojo who said that training and education is an effort to develop the ability both intellectually and personally so that from it will result in behavioral change (Notoatmojo, 2009: 28-33). Behavior changes certainly not only provide benefits for the teacher, but also will have a positive effect on the output of the school. In fact, advancing the development of human resources in SMA Negeri I Adonara Timur by providing training and education is the right way and proven to have a positive impact on improving the quality of education. With the implementation of human resources development program will have an impact on the quality of the school itself in the eyes of the community. According to Cahyono (1996: 157), the implementation of the human resources development program can be seen as one of the most important things. their positions to find results and efficiency work as much as possible; To improve the quality of work to be done and to get results; To master as soon as possible new ways of working. Implementation of a human resource development program can be interpreted as an activity where employees work in order to improve the professionalism of their work. Increased professionalism of this work will have an impact on improving the performance of the employees themselves. In line with this, with the increasing professionalism of work among teachers and administration in SMA Negeri I Adonara Timur, it has an impact on improving the quality and quality of schools.

3.Result of Implementation of Human Resource Development in SMA Negeri I Adonara Timur. From all research conducted by interview, observation, and documentation study at research location, it can be described that human resource development in SMA Negeri I Adonara Timur is oriented to two outcomes. That is the specific result related to the improvement of the quality of the teacher itself, as well as the general result that is about the effect or impact of the increase of quality of teachers on the quality of education (graduation rate). Due to the result of the synergy teacher development program and the impact on the quality of the graduates. Based on the data obtained in the field, the results achieved from the development of human resources in SMA Negeri I Adonara Timur included in the category satisfactory. This is supported by the facts of school leaders who argue that their subordinates (teachers) do not experience significant difficulties in teaching, this fact is compared with other facts about the passing rate of schools that reach 100\%. According Siagian (1998: 183) human resources development oriented to longterm investment. Thus, with the development of human resources in SMA Negeri I bring the results for long-term investment not only to improve the quality of education in the present time but the professional teachers and administration that has been developed, will continue to produce results in improving the quality of education in SMA Negeri I Adonara Timur in the future.

\section{Conclusion}

1. Planning of human resources development management in SMA Negeri I Adonara Timur implemented by the school leadership by doing regular observation to all subordinates. Thus, from these observations the leadership can determine what needs are needed and what development programs are needed in an effort to improve the quality of education in SMA Negeri I Adonara Timur.

2. Implementation of human resource development program in SMA Negeri I Adonara Timur has been going on and on continuously. Implementation of human resource development in SMA Negeri I Adonara Timur is through training and education, concretely implemented in the form of activities such as MGMP, curriculum socialization, upgrading, workshops, training, panel discussions, scientific discussions, and the existence of the plan of study program continued for certain teachers. Implementation of these programs on a regular basis and is mandatory and received direct supervision from the leadership.

3. The results of the implementation of human resource development management in SMA Negeri I Adonara Timur lead to two achievements, namely: the results in particular and the results in general. Specific results of achievement are measured by improvements in teacher quality and performance. While 
the achievement of the results is generally measured from the high percentage of graduation and also the high percentage in the selection of admissions at state universities at provincial and national levels.

\section{Conclusion}

1. Planning of human resources development management in SMA Negeri I Adonara Timur implemented by the school leadership by doing regular observation to all subordinates. Thus, from these observations the leadership can determine what needs are needed and what development programs are needed in an effort to improve the quality of education in SMA Negeri I Adonara Timur.

2. Implementation of human resource development program in SMA Negeri I Adonara Timur has been going on and on continuously. Implementation of human resource development in SMA Negeri I Adonara Timur is through training and education, concretely implemented in the form of activities such as MGMP, curriculum socialization, upgrading, workshops, training, panel discussions, scientific discussions, and the existence of the plan of study program continued for certain teachers. Implementation of these programs on a regular basis and is mandatory and received direct supervision from the leadership.

3. The results of the implementation of human resource development management in SMA Negeri I Adonara Timur lead to two achievements, namely: the results in particular and the results in general. Specific results of achievement are measured by improvements in teacher quality and performance. While the achievement of the results is generally measured from the high percentage of graduation and also the high percentage in the selection of admissions at state universities at provincial and national levels.

\section{Recomendation}

1. In running the development, the head and representative of SMA Negeri I Adonara Timur should be more inofativ, so the programs that have long can be modified without having to eliminate them. For example by bringing provincial-level educational leaders in providing seminars or discussions.

2. Recruitment of faculty and administrative honorary should be more selective, so the quality and quality of SMA Negeri I can still be maintained or even can be improved.

3. Provide tougher sanctions in disciplinary breaches by teachers and administration. So that in itself emerges the effects of geography and shame culture that is rooted not because forced.

4. Leaders should be more active in finding scholarships or grants in order to provide opportunities for teachers to continue their studies to higher levels of jejang. So the quality and quality of school will be better.

5. Teachers and administrators should be more active in self-development, not just by following the programs of the school but having to innovate. Teachers should also enrich themselves with the various teaching methods offered. So it can foster student interest in following the lesson.

\section{References}

[1] Bungin, M. Burhan. 2008. Penelitian Kualitatif; Komunikasi, Ekonomi, Kebijakan Publik, dan Ilmu Sosial Lainnya. Jakarta: Kencana.

[2] Cahyono, B. T. 1996. Modul Manajemen Sumber Daya Manusia. Jakarta: Badan Penerbit IPWI.

[3] Handoko, T. Hani, 2001. Manajemen Personalia dan Sumber Daya Manusia, Edisi 2. Yogyakarta: BPFE-Yogyakarta.

[4] Hasibuan, M.S.P., 2002. Manajemen Sumber Daya Manusia. Dasar dan Kunci Keberhasilan. Jakarta: PT. Gunung Agung.

[5] Kambey, Daniel C. 2012. Pengantar Manajemen. Manado: Tri Ganesha Nusantara.

[6] Manajemen Sumber Daya Manusia. 2012. Manado: Triganesha Nusantara.

[7] Kamus Besar Bahasa Indonesia. 1990. Jakarta: Balai Pustaka.

[8] Mantja, W. 2007. Profesionalisasi Tenaga Kependidikan: Manajemen Pendidikan dan Supervisi Pengajaran. Malang: Elang Mas.

[9] Moleong, L.J. 2007. Metode Penelitian Kualitatif. Bandung: Remaja Rosdakarya.

[10] Mustari. 2014. Manajemen Pendidikan. Jakarta: Raja Grafindo Persada.

[11] Notoadmodjo, Soekidjo. 2009. Pengembangan Sumber daya manusia. Jakarta: Rineka Cipta.

[12] Riduwan, 2009. Belajar Mudah Penelitian untuk Guru-Karyawan dan Peneliti Pemula. Bandung: Alfabeta.

[13] Siagian, Sondang P. 1998. Manajemen Sumber Daya Manusia. Jakarta: Bumi Aksara. 
[14] Sugiyono.2011. Metode Penelitian Kuantitatif, Kualitatif, dan R\&D. Bandung: Alfabeta.

[15] Suharso, 2011. Kamus Besar Bahasa Indonesia. Semarang: Widya Karya.

[16] Sukmadinata, Nana Syaodih. 2005. Metode Penelitian Pendidikan. Bandung: Remaja Rosda Karya. 